\title{
The behavior of osteoblast-like cells on various substrates with functional blocking of integrin- $\beta 1$ and integrin- $\beta 3$
}

\author{
M. C. Siebers $\cdot$ X. F. Walboomers $\cdot$ J. van den Dolder • \\ S. C. G. Leeuwenburgh · J. G. C. Wolke · J. A. Jansen
}

Received: 10 October 2006/ Accepted: 8 February 2007/Published online: 31 July 2007

(C) Springer Science+Business Media, LLC 2007

\begin{abstract}
This study was designed to examine the influence of integrin subunit- $\beta 1$ and subunit- $\beta 3$ on the behavior of primary osteoblast-like cells, cultured on calcium phosphate $(\mathrm{CaP})$-coated and non coated titanium (Ti). Osteoblast-like cells were incubated with specific monoclonal antibodies against integrin- $\beta 1$ and integrin- $\beta 3$ to block the integrin function. Subsequently, cells were seeded on Ti discs, either non coated or provided with a $2 \mu \mathrm{m}$ carbonated hydroxyapatite coating using Electrostatic Spray Deposition. Results showed that on CaP coatings, cellular attachment was decreased after a pre-treatment with either anti-integrin- $\beta 1$ or anti-integrin- $\beta 3$ antibodies. On Ti, cell adhesion was only slightly affected after a pre-treatment with anti-integrin- $\beta 3$ antibodies. Scanning electron microscopy showed that on both types of substrate, cellular morphology was not changed after a pre-treatment with either antibody. With quantitative PCR, it was shown for both substrates that mRNA expression of integrin- $\beta 1$ was increased after a pre-treatment with either anti-integrin- $\beta 1$ or anti-integrin- $\beta 3$ antibodies. Furthermore, after a pre-treatment with either antibody, mRNA expression of integrin- $\beta 3$ and ALP was decreased, on both types of substrate. In conclusion, osteoblast-like cells have the ability to compensate to great extent for the blocking strategy as applied here. Still, integrin- $\beta 1$ and $\beta 3$ seem to play different roles in attachment, proliferation, and differentiation of osteoblast-like cells, and responses on CaP-coated substrates differ to non coated Ti. Furthermore, the influence on ALP
\end{abstract}

M. C. Siebers - X. F. Walboomers - J. van den Dolder . S. C. G. Leeuwenburgh · J. G. C. Wolke · J. A. Jansen ( $\square)$ Department of Periodontology and Biomaterials, College of Dental Science 309, Radboud University Nijmegen Medical Centre, NijmegenPO Box 9101, 6500 HB, The Netherlands e-mail: j.jansen@dent.umcn.nl expression suggests involvement of both integrin subunits in signal transduction for cellular differentiation.

\section{Introduction}

For implants used in orthopedic or dental surgery the implant-to-bone contact is influenced by the characteristics of the implant, like the surface structure and chemical composition. Regarding the latter, calcium phosphate (CaP) coatings have shown to favor the bone response in vivo $[1,2]$. However, the mechanism responsible for the improved osteogenic response to $\mathrm{CaP}$ coatings is still not clear. Studying the mechanism in vivo is complicated by many factors. Still, cell culture models can be designed to study (parts of) the underlying mechanisms.

In vitro, it is known that cells attach to extracellular matrix (ECM) proteins, which are adsorbed to the surface of the material. Specific transmembrane proteins, called integrins, connect the cells to the ECM proteins. These integrins consist of an $\alpha$ - and a $\beta$-unit. Osteoblasts generally express integrin subunits $\alpha 1, \alpha 2, \alpha 3, \alpha 4, \alpha 5, \alpha 6, \alpha \mathrm{v}, \beta 1, \beta 3$, and $\beta 5$ [3]. In Table 1 , an overview is listed of combinations of integrin subunits and their protein ligands [4]. Important ECM proteins for the attachment of osteoblasts are fibronectin, collagen type I, and vitronectin. For attachment to fibronectin and collagen type I, osteoblasts can express integrin subunit$\beta 1$. For attachment to vitronectin, they may use integrin subunit- $\beta 3$ [5]. Once cells have attached, the integrin is also involved in passing information from the ECM to the cell ("outside-in-signaling"), and from the cell towards the ECM ("inside-out-signaling) [6]. These signaling pathways can regulate cellular adhesion, migration, and subsequent behavior to a great extent. 
Table 1 An overview of possible integrin subunits and their protein ligands [2]

\begin{tabular}{lll}
\hline Subunits & \multicolumn{2}{l}{ Ligands } \\
\hline$\beta 1$ & $\alpha 1$ & Collagens, Laminins \\
& $\alpha 2$ & Collagens, Laminins \\
& $\alpha 3$ & Fibronectin, Collagen, Laminin \\
& $\alpha 4$ & Fibronectin, VCAM \\
& $\alpha 5$ & Fibronectin \\
& $\alpha 6$ & Laminins \\
& $\alpha 7$ & Laminins \\
& $\alpha 8$ & Fibronectin \\
& $\alpha 9$ & Tenascin, Osteopontin \\
$\beta 2$ & Av & Fibronectin, Vitronectin \\
& AL & ICAMs \\
& $\alpha \mathrm{M}$ & Fibrinogen \\
$\beta 3$ & AX & Fibrinogen \\
$\beta 4$ & Iib & Fibrinogen, Fibronectin, Vitronectin \\
$\beta 5$ & Av & Fibrinogen, Fibronectin, Vitronectin, BSP \\
$\beta 6$ & $\alpha 6$ & Laminin \\
\hline & Av & Vitronectin \\
& & Fibronectin \\
\hline
\end{tabular}

In this study the importance of integrins in the boneimplant-interface was examined on two different implant materials (either CaP-coated or non coated $\mathrm{Ti}$ ), with the functional blocking of integrins. We hypothesize that blocking integrin- $\beta 1$ and integrin- $\beta 3$ with specific antibodies will have an inhibitory effect on the initial attachment, and thus will delay proliferation and early differentiation of osteoblast-like cells. Furthermore, we hypothesize that differences in cellular response exist between cultures on $\mathrm{CaP}$ coatings and non coated Ti. For this purpose, carbonated hydroxyapatite (HA) coatings were deposited with the electrostatic spray deposition (ESD) technique. Subsequently, anti-integrin- $\beta 1$ and antiintegrin- $\beta 3$ antibodies were added to primary osteoblastlike cells, and cells were cultured on both substrates. The initial cellular attachment, proliferation, and cell shape were evaluated. Further, gene expression for integrins $\beta 1$ and $\beta 3$, and alkaline phosphatase, was examined with quantitative PCR. Results were compared to cultures without antibodies added to the cells on both materials.

\section{Materials and methods}

\section{Substrates}

Disc-shaped commercially pure (cp) Ti substrates with a diameter of $12 \mathrm{~mm}$ and a thickness of $1.5 \mathrm{~mm}$ were cleaned ultrasonically in isopropanol for $5 \mathrm{~min}$. Subsequently, the substrates were not coated, or provided with a $\mathrm{CaP}$ coating using the ESD technique.

The ESD coating procedure was performed using a vertical ESD set-up (Advanced Surface Technology, Bleiswijk, The Netherlands) with a two component-nozzle, as described previously $[7,8]$. The solvents for the coating consisted of $6.25 \mathrm{mM} \mathrm{Ca}\left(\mathrm{NO}_{3}\right)_{2} \cdot 2 \mathrm{H}_{2} \mathrm{O}$ and $3.5 \mathrm{mM} \mathrm{H}_{3} \mathrm{PO}_{4}$ in butyl carbitol. The applied voltage was $6.3-6.4 \mathrm{kV}$, the flow rate $1 \mathrm{~mL}$ per hour per solvent, the deposition time $45 \mathrm{~min}$, and the substrate temperature $350{ }^{\circ} \mathrm{C}$. The nozzle-to-substrate distance was $20 \mathrm{~mm}$. The deposited coatings had a thickness of $2 \mu \mathrm{m}$. After deposition, the substrates were subjected to an additional heat-treatment for $2 \mathrm{~h}$ at a temperature of $700{ }^{\circ} \mathrm{C}$ in air to crystallize the coating. After the heat-treatment, coatings were characterized by X-ray diffraction, Fourier-transform infrared, and scanning electron microscopy combined with electron dispersive spectroscopy, as crystalline carbonated hydroxyapatite, with a $\mathrm{Ca} / \mathrm{P}$ ratio of 1.9-2.0 and a uniform porous surface morphology. Before use in the in vitro assays, all substrates were sterilized $15 \mathrm{~min}$ at $121{ }^{\circ} \mathrm{C}$ in an autoclave.

\section{Cell culture}

Rat bone marrow (RBM) cells were isolated and cultured to obtain osteoblast-like cells, using a method adapted from Maniatopoulos et al. [9]. For each individual run, RBM cells were obtained from both femora of one male Wistar WU rat (40-43 days old). Femora were washed four times in alpha-Minimal Essential Medium ( $\alpha$-MEM; Gibco BRL, Life Technologies B.V. Breda, The Netherlands) with $0.5 \mathrm{mg} / \mathrm{mL}$ gentamycin and $3 \mu \mathrm{g} / \mathrm{mL}$ fungizone. Epiphyses were cut off and diaphyses flushed out with $30 \mathrm{~mL}$ culture medium $(\alpha$-MEM, supplemented with $10 \%$ fetal calf serum (FCS; Gibco), $50 \mu \mathrm{g} / \mathrm{mL}$ ascorbic acid (Sigma, Chemical Co., St. Louis, MO, USA), $50 \mu \mathrm{g} / \mathrm{mL}$ gentamycin, $10 \mathrm{mM}$ $\mathrm{Na}-\beta$-glycerophosphate (Sigma), and $10^{-8} \mathrm{M}$ dexamethasone (Sigma)). The flush-out of both femora was pooled and divided over three culture flasks $\left(75 \mathrm{~cm}^{2}\right)$. Cells were incubated in a humidified atmosphere of $95 \%$ air, $5 \% \mathrm{CO}_{2}$ at $37^{\circ} \mathrm{C}$. After 7 days of primary culture osteoblast-like cells were detached using trypsin/EDTA $(0.25 \% \mathrm{w} / \mathrm{v}$ trypsin/0.02\% EDTA).

Blocking with specific antibodies

Integrin blocking was applied as described by McNally et al. [10]. Osteoblast-like cells were concentrated by centrifugation (350 g, $5 \mathrm{~min})$, counted with a Coulter ${ }^{\circledR}$ Counter (Coulter Electronics Ltd., Luton, United Kingdom), concentrated by centrifugation $(1,500 \mathrm{rpm}, 5 \mathrm{~min})$, and resuspended to a concentration of $1.5 \times 10^{6}$ cells in $1 \mathrm{~mL}$ 
PBS/BSA $0.5 \%$. In the experimental groups, specific monoclonal anti-integrin- $\beta 1$ antibodies or anti-integrin- $\beta 3$ antibodies (Ha2/5 or 2 C9.G2, respectively, both from BD Biosciences Pharmingen, NJ, USA) were added to the cells in a concentration of $50 \mu \mathrm{g} / \mathrm{mL}$. The experimental groups were incubated at $4{ }^{\circ} \mathrm{C}$ for $30 \mathrm{~min}$ to allow antibodies to interact with the integrins on the osteoblast-like cells. The control group consisted of osteoblast-like cells without antibodies added, and was also incubated at $4{ }^{\circ} \mathrm{C}$ for $30 \mathrm{~min}$.

\section{Cell seeding}

After 30 min of incubation with or without integrin antibodies, cells were concentrated by centrifugation (350 g, $5 \mathrm{~min}$ ) and resuspended in culture medium. Cells were again counted with a Coulter ${ }^{\circledR}$ Counter, and seeded on the substrates at a concentration of 11,500 cells per $\mathrm{cm}^{2}$.

Initial attachment and total cell amount

After 30, 60, 120, and 240 min of incubation, and 1 and 3 days of culture, substrates were washed with PBS to remove all non-adherent cells, and placed in a new 24-well plate. Attached cells were released from the substrate with $0.5 \mathrm{~mL}$ trypsin/EDTA. After $5 \mathrm{~min}$ of incubation in $37^{\circ} \mathrm{C}$, $0.5 \mathrm{~mL}$ culture medium was added to block the enzymatic activity of the trypsin, and cells were counted with a Coulter ${ }^{\circledR}$ Counter. Cellular attachment was normalized to the values of the control group after 30 min of incubation on the relevant substrate (set at $100 \%$ ). All substrates were routinely observed with light microscopy, to confirm the efficacy of the detachment procedure.

\section{Scanning electron microscopy (SEM)}

To observe changes in cell morphology, SEM was performed after 1 and 3 days of culture. Substrates were washed twice with PBS, and fixation was carried out for 5 min in $2 \%$ gluteraldehyde. Subsequently, substrates were washed with $0.1 \mathrm{M}$ sodium-cacodylate buffer ( $\mathrm{pH} 7.4$ ), dehydrated in a graded series of ethanol, and dried in tetramethylsilane. The substrates were sputter-coated with gold and examined using a Jeol 6310 SEM (Tokyo, Japan).

\section{Real time quantitative RT-PCR}

The gene expression for integrins $\beta 1$ and $\beta 3$, and alkaline phosphatase was also examined. After 1 and 3 days of culture, RNA was isolated from the cells using a RNA isolation kit (Qiagen, Hilden, Germany). After the isolation of the RNA, the reverse transcriptase (RT)-reaction was performed. The cDNA from the RT-reaction was used as a template in the polymerase chain reaction (PCR). To perform quantitative PCR, $4.5 \mu \mathrm{L}$ RNase-free water, $12.5 \mu \mathrm{L}$ $\mathrm{SYBR}^{\circledR}$ Green MasterMix (Eurogentec, Liege, Belgium), $5 \mu \mathrm{L}$ cDNA, $1.5 \mu \mathrm{L}$ Reverse Primer and $1.5 \mu \mathrm{L}$ Forward Primer were added to a QRT-PCR-96-well plate. This plate was sealed, and the Q-PCR-run was performed with the MyiQ Single-Color Real-Time Detection System for quantification with $\mathrm{SYBR}^{\circledR}$ Green and melting curve analysis (Biorad, Richmond, CA, USA). DNA was PCRamplified under the following conditions: $2 \mathrm{~min}$ at $50{ }^{\circ} \mathrm{C}$ and $10 \mathrm{~min}$ at $95^{\circ} \mathrm{C}$, followed by 40 cycles of $15 \mathrm{~s}$ at $95{ }^{\circ} \mathrm{C}$ and $1 \mathrm{~min}$ at $60{ }^{\circ} \mathrm{C}$, with data collection in the last $30 \mathrm{~s}$. The used primers are listed in Table 2 . The reference household-gene used to normalize the amount of mRNA in the cultures was GAPDH $\left(\Delta \mathrm{C}_{\mathrm{T}}=\mathrm{C}_{\mathrm{T} \text {,gene of interest }}-\mathrm{C}_{\mathrm{T}, \mathrm{GAPDH}}\right.$ (1)). Gene expression was measured relative to the gene expression of cultures on the relevant substrates (either CaP-coated or non coated $\mathrm{Ti}$ ) that had not received antibodies, after day 1 of culture $\left(\Delta \Delta \mathrm{C}_{\mathrm{T}}=\Delta \mathrm{C}_{\mathrm{T} \text {,sample }}-\right.$ $\left.\Delta \mathrm{C}_{\mathrm{T} \text {,control }}(2)\right)$. The fold change in gene expression relative to the control was calculated by $2^{-\Delta \Delta C T}$ (3) [11].

Statistical analysis

All assays were performed in triplicate. Statistical analysis for initial attachment and total cell amount was performed using a two-way ANOVA. As post-hoc comparison, a Tukey test was performed. A probability $(P)$ value less than 0.05 was considered statistically significant. The experiments was replicated multiple times, but only the two independent experiments which were most representative for the results obtained overall are presented in the current investigation, and hereafter termed 'run 1' and 'run 2'.

\section{Results}

Initial attachment and total cell amount

\section{CaP-coated substrates}

In the first run, the initial cellular attachment was decreased after $30 \mathrm{~min}$ for $\pm 30 \%$ after a pre-treatment with anti-integrin- $\beta 1$ antibodies $(P<0.05)$. With a pre-treatment of anti-integrin- $\beta 3$ antibodies, initial attachment was decreased for $\pm 40 \%$ after 30 and $60 \mathrm{~min}(P<0.01)$ (Fig. $1 \mathrm{~A}$, $\mathrm{B})$. In the second run, a pre-treatment with anti-integrin- $\beta 1$ antibodies gave a reduction of $\pm 20-30 \%$ in cellular attachment after 60 and $240 \mathrm{~min}$, and after 1 day $(P<0.05)$. A pre-treatment with anti-integrin- $\beta 3$ antibodies decreased cellular attachment for $40-50 \%$ after 30 $(P<0.01), 60,240 \min (P<0.05), 1$ day $(P<0.01)$, and 3 days $(P<0.05)$ (Fig. 2 A, B). 
Table 2 Overview of the amplification primers used for QRT-PCR

\begin{tabular}{|c|c|c|}
\hline & Forward primer & Reverse primer \\
\hline integrin- $\beta 1$ & 5'TGGTCAGCAGCGCATATCTG3' & 5'TGCATCAAAGCCACCTTCTG3' \\
\hline integrin- $\beta 3$ & 5'CCACTGATGCCAAGACCCATA3' & 5'AGACAATGCCTGCCAGCCT3' \\
\hline ALP & 5'GCTTCACGGCATCCATGAG3' & 5'GAGGCATACGCCATGACGT3' \\
\hline GAPDH & 5'GCTTTGTGCAGTGCCAGCC3' & 5'CACCGACCTTCACCATCTTGT3' \\
\hline
\end{tabular}

Fig. 1 Cellular attachment in the first run. (A) and (B) CaPcoated substrates derived with Electrostatic Spray Deposition $(\mathrm{ESD}) ;(\mathbf{C})$ and $(\mathbf{D})$ non-coated Ti. * indicates a significant difference between the control group and the experimental group with the pre-treatment with anti-integrin- $\beta 1$ antibodies. \# indicates a significant difference between the control group and the experimental group that was pre-treated with anti-integrin- $\beta 3$ antibodies
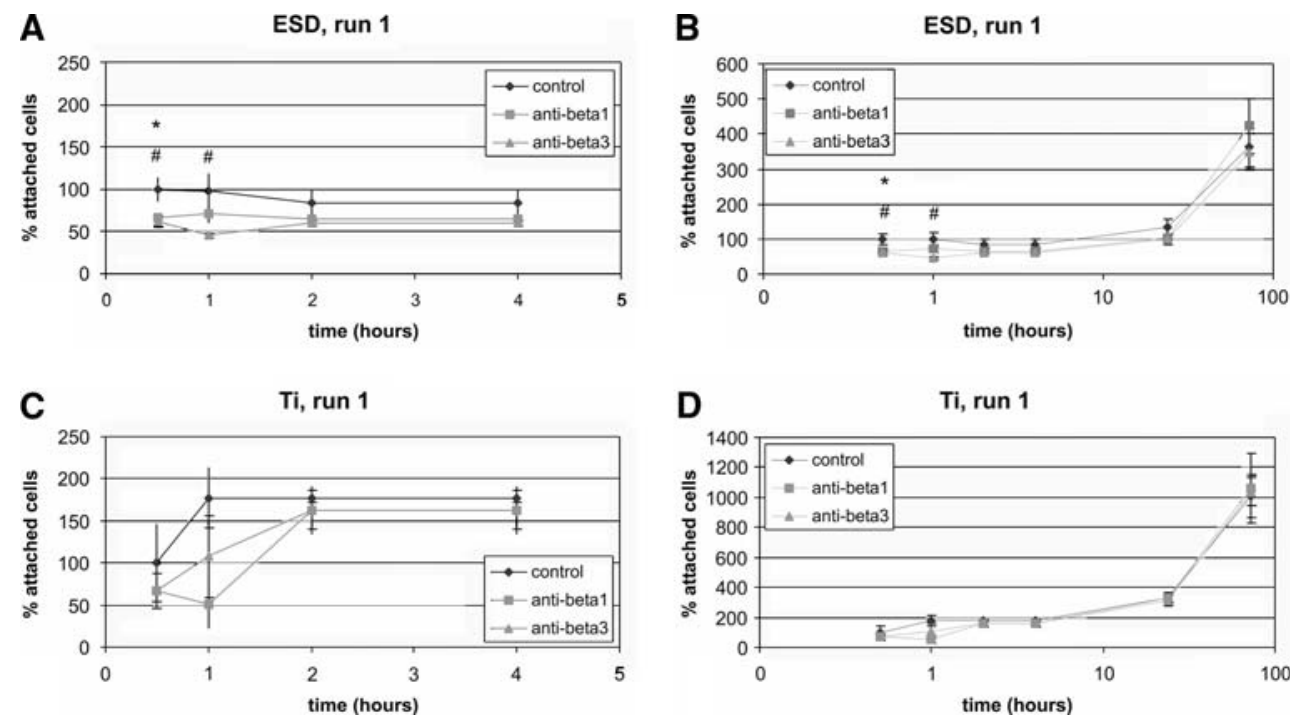

\section{Non coated Ti substrates}

In general, integrin blocking had a less effect on the bare $\mathrm{Ti}$ substrates. In the first run, no differences were observed in initial cellular attachment or cell number with a pre-treatment of anti-integrin- $\beta 1$ or anti-integrin- $\beta 3$ antibodies, although the means are quite different. Possibly, if the error were smaller, it would emerge that the function blocking antibodies were indeed effective (Fig.1C, D). However, also in the second run, no differences in initial attachment were observed with the pre-treatment of anti-integrin- $\beta 1$ antibodies. However, with a pre-treatment of anti-integrin$\beta 3$ antibodies, a decrease of $\pm 30 \%$ in attachment was seen after 30 and $60 \min (P<0.05)$ (Fig. 2C, D).

\section{SEM}

\section{CaP-coated substrates}

In both runs, osteoblast-like cells on CaP-coated substrates had attached and spread over the substrate surface after 1 day of culture (Fig. 3A). Cells exhibited a typical phenotype for osteoblasts in culture, i.e. a flat monolayer with multiple cell extensions, and frequent cell-to-cell contact. After 3 days of culture, cells were more elongated and more numerous. Pre-treatment with either anti-integrin- $\beta 1$ antibodies (Fig. 3B) or anti-integrin- $\beta 3$ antibodies (Fig. 3C) did not noticeably change cellular morphology upon visual inspection.

\section{Non coated Ti substrates}

On non coated Ti-substrates, osteoblast-like cells were also stretched out over the surface after 1 day of culture (Fig. 3D). After 3 days, more cells were present, which were well spread. After pre-treatment with both specific antibodies (Fig. 3E, F), no changes in morphology were observed, after both 1 and 3 days of culture.

\section{Real time quantitative RT-PCR}

Real time quantitative RT-PCR (QRT-PCR) was performed to determine the gene expression relative to the control group (cell culture without a pre-treatment with integrin antibodies). The results of QRT-PCR are listed in Table 3 .

mRNA expression of integrin- $\beta 1$ on $C a P$-coated substrates

In the control groups, mRNA expression of integrin- $\beta 1$ increased from day 1 to day 3 . In the first run, after a 
Fig. 2 Cellular attachment in the second run. (A) and (B) CaP-coated substrates derived with Electrostatic Spray Deposition (ESD); (C) and (D) non-coated Ti. * indicates a significant difference between the control group and the experimental group with the pre-treatment with anti-integrin$\beta 1$ antibodies. " indicates a significant difference between the control group and the experimental group that was pre-treated with anti-integrin- $\beta 3$ antibodies

Fig. 3 Scanning electron micrographs of osteoblast-like cells on CaP-coated (A, B, and C) substrates, and non-coated (D, E, and F) Ti substrates after 1 day of culture. There were no morphological differences between the control group (A and $\mathbf{D}$ ), or the experimental groups that were either pretreated with anti-integrin- $\beta 1$ antibodies (B and $\mathbf{E}$ ), or antiintegrin- $\beta 3$ antibodies $(\mathbf{C}$ and $\mathbf{F})$
A

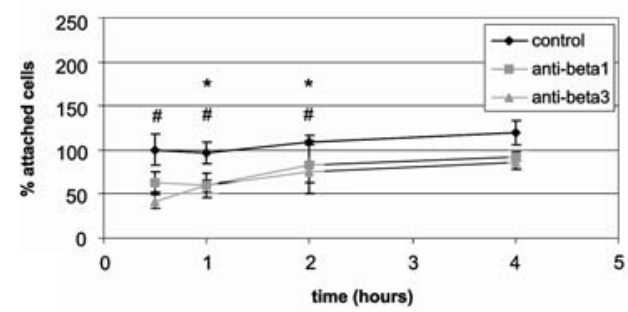

C

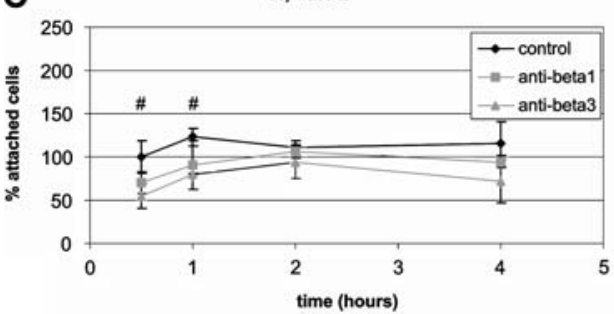

B

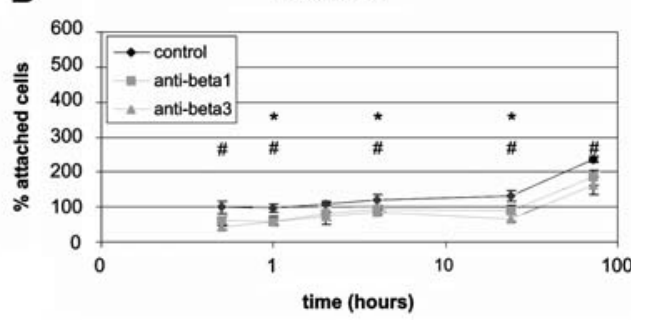

D

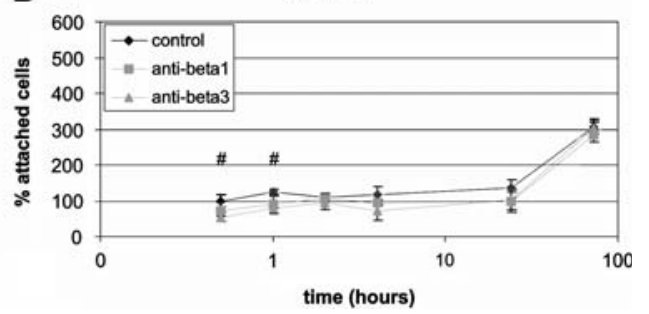

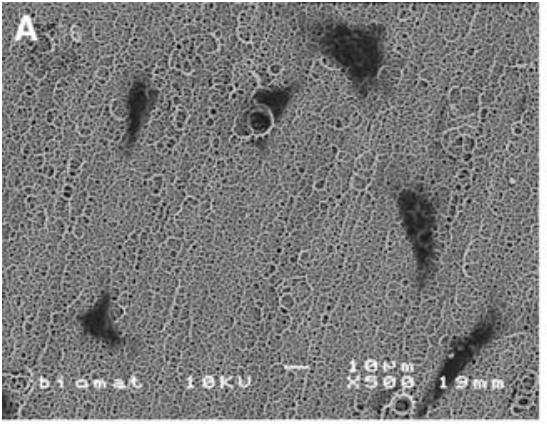
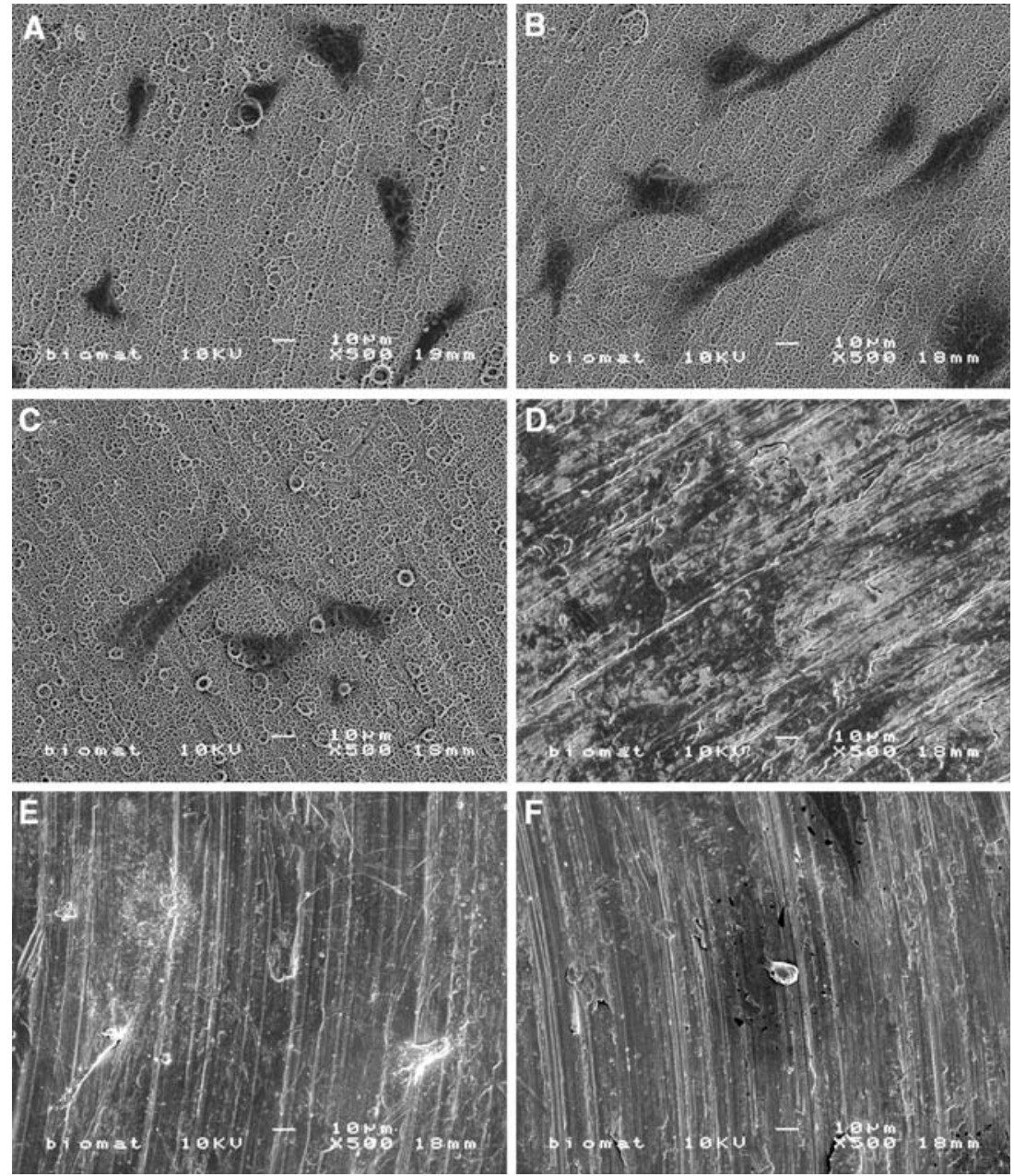

pre-treatment with either anti-integrin- $\beta 1$ or anti-integrin$\beta 3$ antibodies, mRNA of integrin- $\beta 1$ was increased, compared to the control group, after 1 and 3 days of culture
(Table 3). In the second run, a similar increase was seen, which however was delayed until day 3 for both experimental groups. 
Table 3 mRNA expression. Listed are the normalized changes (percentages) in mRNA expression of integrins- $\beta 1$ and 3 , and ALP, relative to the control group after 1 day of culture on both types of substrate

\begin{tabular}{|c|c|c|c|c|c|}
\hline \multicolumn{6}{|c|}{ MRNA expression of integrin- $\beta 1$ (percentages) } \\
\hline & & \multicolumn{2}{|l|}{ run 1} & \multicolumn{2}{|l|}{ run 2} \\
\hline & & day 1 & day 3 & day 1 & day 3 \\
\hline \multirow[t]{3}{*}{ CaP-coated } & control & 100 & 134 & 100 & 492 \\
\hline & anti-integrin- $\beta 1$ & 570 & 220 & 84 & 513 \\
\hline & anti-integrin- $\beta 3$ & 453 & 196 & 107 & 566 \\
\hline \multirow[t]{3}{*}{$\mathrm{Ti}$} & control & 100 & 243 & 100 & 392 \\
\hline & anti-integrin- $\beta 1$ & 222 & 554 & 154 & 636 \\
\hline & anti-integrin- $\beta 3$ & 320 & 426 & 145 & 794 \\
\hline \multicolumn{6}{|c|}{ mRNA expression of integrin- $\beta 3$ (percentages) } \\
\hline \multirow[t]{3}{*}{ CaP-coated } & control & 100 & 19 & 100 & 14 \\
\hline & anti-integrin- $\beta 1$ & 71 & 8 & 50 & 21 \\
\hline & Anti-integrin- $\beta 3$ & 41 & 9 & 30 & 15 \\
\hline \multirow[t]{3}{*}{$\mathrm{Ti}$} & control & 100 & 39 & 100 & 140 \\
\hline & anti-integrin- $\beta 1$ & 149 & 12 & 817 & 91 \\
\hline & anti-integrin- $\beta 3$ & 48 & 10 & 673 & 701 \\
\hline \multicolumn{6}{|c|}{ mRNA expression of ALP (percentages) } \\
\hline \multirow[t]{3}{*}{ CaP-coated } & control & 100 & 49 & 100 & 50 \\
\hline & Anti-integrin- $\beta 1$ & 84 & 4 & 92 & 33 \\
\hline & Anti-integrin- $\beta 3$ & 73 & 1 & 17 & 31 \\
\hline \multirow[t]{3}{*}{$\mathrm{Ti}$} & control & 100 & 50 & 100 & 20 \\
\hline & Anti-integrin- $\beta 1$ & 127 & 4 & 58 & 4 \\
\hline & Anti-integrin- $\beta 3$ & 86 & 39 & 2 & 5 \\
\hline
\end{tabular}

mRNA expression of integrin- $\beta 1$ on non coated Ti substrates

Also on the bare $\mathrm{Ti}$, the mRNA expression of integrin- $\beta 1$ was increased in the control group after 3 days of culture. In the first run, a pre-treatment with anti-integrin- $\beta 1$ antibodies increased the mRNA expression of integrin- $\beta 1$. A pre-treatment with anti-integrin- $\beta 3$ antibodies also gave an increase in mRNA of integrin- $\beta 1$ (Table 3 ). In the second run similar trends were seen. However, now the increase was delayed, either after a pre-treatment with antiintegrin- $\beta 1$ or anti-integrin- $\beta 3$ antibodies.

\section{mRNA expression of integrin- $\beta 3$ on CaP-coated substrates}

Opposite to the expression of integrin- $\beta 1$, the mRNA expression of integrin- $\beta 3$ was decreased on the control sample after 3 days of culture. In both performed runs, a pre-treatment with either anti-integrin- $\beta 1$ or anti-integrin$\beta 3$ antibodies decreased the mRNA of integrin- $\beta 3$, after 1 and 3 days of culture (Table 3 ).
mRNA expression of integrin- $\beta 3$ on non coated $T i$ substrates

In the first run, the control group had a decreased mRNA expression of integrin- $\beta 3$ after 3 days of culture. After a pre-treatment of the cells with anti-integrin- $\beta 1$ antibodies, mRNA of integrin- $\beta 3$ was increased after 1 day, but decreased after 3 days of culture. A pre-treatment with anti-integrin- $\beta 3$ antibodies decreased mRNA of integrin- $\beta 3$ after 1 and 3 days of culture. In the second run, mRNA of integrin- $\beta 3$ in the control group was increased from day 1 to day 3 . A pre-treatment with anti-integrin- $\beta 1$ antibodies increased mRNA of integrin- $\beta 3$ after 1 day of culture, and decreased after 3 days of culture. After a pre-treatment with anti-integrin- $\beta 3$ antibodies, mRNA expression of integrin- $\beta 3$ was increased after both 1 and 3 days of culture (Table 3).

mRNA expression of ALP on CaP-coated substrates

The mRNA expression of ALP in the control group decreased from day 1 to day 3 . A pre-treatment of the cells 
with either anti-integrin- $\beta 1$ or anti-integrin- $\beta 3$ antibodies decreased the mRNA of ALP after 1 and 3 days of culture (Table 3).

\section{mRNA expression of ALP on non coated Ti substrates}

In the control group, mRNA expression of ALP was decreased from day 1 to day 3 . A pre-treatment with antiintegrin- $\beta 1$ antibodies decreased the mRNA expression of ALP. A decrease in mRNA of ALP was also observed after a pre-treatment with anti-integrin- $\beta 3$ antibodies (Table 3 ).

\section{Discussion and conclusion}

Integrins are involved in the attachment of cells to the proteins that are adsorbed to the surface of a substrate or implant $[3,4]$. Furthermore, they are relevant for the signaling of the ECM with the cell and of the cell with the ECM, influencing cellular behavior $[5,6]$. This study examined the effects of blocking integrin- $\beta 1$ or integrin- $\beta 3$ with specific monoclonal antibodies on the cellular behavior of primary osteoblast-like cells cultured on an ESD-derived CaP coating, or on non coated Ti substrates. The results showed an affected initial attachment, and an altered mRNA expression of integrin- $\beta 1$, integrin- $\beta 3$, and ALP, when the function of integrin- $\beta 1$ or integrin- $\beta 3$ was inhibited.

First, general remarks have to be made regarding the method used to block the integrins. Osteoblast-like cells were pre-treated with monoclonal antibodies in PBS/BSA $0.5 \%$ and incubated at $4{ }^{\circ} \mathrm{C}$ for $30 \mathrm{~min}$, as previously employed by multiple researchers $[10,12,13]$. No serum was added to the cell suspension while the antibodies were incubated to avoid competitive binding of the antibodies with serum proteins. In contrast, another study describes the addition of antibodies to the cells, in complete culture medium after seeding them on the substrates [14]. Using this latter method, the antibodies only influenced cell signaling, as cells had already adhered. In the present study, the antibodies were added in suspension before cell seeding on the substrates. Using this method, all integrins on the surface were blocked, affecting the function of integrins in both attachment and cell signaling. Moreover, in the current study blocking antibodies were used at a concentration of $50 \mu \mathrm{g} / \mathrm{mL}$, which is very likely to be a saturating concentration. However, at high antibody concentrations, even nonspecific IgGs could possibly have had some inhibitory effect on cell adhesion. For future experiments, isotypematched nonspecific IgGs should be studied also to control for nonspecific effects. However, such future studies on a comparative analysis of the functions of integrin- $\beta 1$ versus integrin- $\beta 3$ could also concentrate on other methods besides blocking the function with antibodies. General disadvantages of antibody blocking procedures are that the binding affinities, as well as the expression level can differ between the two integrins. More conclusive studies could be performed to compare the functions of integrin- $\beta 1$ and integrin- $\beta 3$, like using knock-out animals or siRNA techniques. Such studies then should encompass not only transcription (as studied here) but be complemented by experiments verifying that integrin protein expression changes (e.g. Western blots or flow cytometry). Integrins are highly regulated at many levels; transcriptional, translational, and post-translational. It is well established that changes in integrin mRNA levels do not always translate to greater integrin protein expression and/or activity.

Concerning the overall study results, it is evident that differences exist between the two performed runs. Several explanations can be given for these observations. First, it is known that integrin expression is a very dynamic process [15-18]. Furthermore, the proteins adsorbed to the surface are not immobile, and the cell itself produces ECM proteins, which influence the integrin expression. Finally, there might be variability between the heterogeneous cell populations of both runs. However, this in vitro-research was designed to determine the importance of integrins in the behavior of primary osteoblast-like cells. Despite the differences between the two runs, the same tendency was observed, confirming that the results are reliable.

CaP-coated and plain Ti materials are both commonly used for the production of dental implants. However, studies have shown a beneficial osteogenic effect of CaPcoated surfaces, compared to Ti [19-21]. Studies attempting to clarify the mechanism behind these beneficial effects have shown that both the chemical composition and surface roughness are of influence on protein adsorption, integrin expression, and subsequently cellular behavior [22-24]. In the present study, the substrates differ in chemical composition, roughness, and morphology, and thus it is not possible to attribute effects on cell behavior to just one of these factors. Therefore, we separated the results of cell cultures on CaP-coated from non coated Ti substrates.

In the first run, cellular attachment early after seeding was affected on CaP-coated substrates following a pre-treatment with anti-integrin- $\beta 1$ or anti-integrin- $\beta 3$ antibodies. Furthermore, mRNA expression of integrin- $\beta 1$ was increased, and the mRNA expression of integrin- $\beta 3$ was decreased. In the second run, initial attachment and total cell amount were decreased when cells were pre-treated with anti-integrin- $\beta 1$ or anti-integrin- $\beta 3$ antibodies. Moreover, mRNA expression of integrin- $\beta 1$ was increased after 3 days of culture, and mRNA expression of integrin- $\beta 3$ was decreased, even in the control groups. From these data, it can be deducted that on the ESD-derived CaP-coated substrates mainly integrin- $\beta 1$ is responsible for cellular attachment. These results corroborate the available literature, which shows that integrin- $\beta 1$ 
always is highly expressed on CaP-coated substrates, whereas integrin- $\beta 3$ is not always present [15-18]. Indeed, many researchers state that integrin- $\beta 1$ is the major subunit in osteoblasts [5, 25, 26].

On non coated Ti substrates, cellular attachment was not affected by the blocking procedure in the first run. Still, mRNA expression of integrin- $\beta 1$ was upregulated, and mRNA of integrin- $\beta 3$ was decreased. In the second run, again attachment was not affected by a pre-treatment with anti-integrin- $\beta 1$ antibodies. However, early cellular attachment was decreased when cells were pre-treated with anti-integrin- $\beta 3$ antibodies. The mRNA expression of integrin- $\beta 1$ was increased after 3 days of culture, and the mRNA of integrin- $\beta 3$ was increased after 1 day of culture. These results suggest an involvement of integrin- $\beta 1$ and integrin$\beta 3$ in the attachment of osteoblast-like cells to non coated Ti. However, in the first run, there is only a small upregulation of mRNA of integrin- $\beta 1$, and no effect on cellular attachment, which is the opposite of the results on CaP-coated substrates. Furthermore, in the second run, an increased mRNA of integrin- $\beta 3$ was observed, but a decrease in early cellular attachment. On bare Ti, osteoblast-like cells have a considerable ability to compensate for cellular attachment, for example with the upregulation of other integrins.

Besides their role as adhesion molecule, integrins also function as signaling receptors. Integrin- $\beta 1$-mediated adhesion to bone matrix induces proliferation, differentiation, and matrix synthesis by osteoblasts [27]. In the present study, after a pre-treatment with either integrin antibody, the mRNA expression of ALP was decreased. This occurred in both runs, and on both types of substrates. Thus it seemed that, despite the increase in mRNA of integrin- $\beta 1$ and integrin- $\beta 3$, signal transduction necessary for osteogenic differentiation was decreased or at least delayed. It has to be noted that without a pre-treatment with anti-integrin- $\beta 1$ or anti-integrin- $\beta 3$ antibodies, mRNA expression of ALP was also decreased in cultures on both types of substrates, when day 1 is compared to day 3 . These results are supported by other studies. For instance, a decreased ALP activity was observed when antibodies against fibronectin $(\alpha 4 \beta 1$ and $\alpha 5 \beta 1)$ or collagen type I $(\alpha 1 \beta 1$ and $\alpha 2 \beta 1)$ were added [14].

In conclusion, we can maintain our hypothesis that blocking of integrin- $\beta 1$ and integrin- $\beta 3$ with antibodies has an inhibitory effect on the attachment and differentiation of osteoblast-like cells. However, osteoblast-like cells have the ability to compensate to great extent for the blocking strategy as applied here. Still, integrin- $\beta 1$ and $\beta 3$ seem to play different roles in attachment, proliferation, and differentiation of osteoblast-like cells, and responses on CaP-coated substrates differ to non coated Ti. Furthermore, the influence on ALP expression suggests involvement of both integrin subunits in signal transduction for cellular differentiation.
Acknowledgements Scanning electron microscopy was performed at the Microscopic Imaging Centre (MIC) of the Nijmegen Centre for Molecular Life Sciences (NCMLS), the Netherlands. This research was supported by the Dutch Technology Foundation STW, grant \#NKG.5546.

\section{References}

1. S. VERCAIGNE, J. G. C. WOLKE, I. NAERT and J. A. JANSEN, Clin. Oral Impl. Res. 9 (1998) 261

2. S. VERCAIGNE, J. G. C. WOLKE, I. NAERT and J. A. JANSEN, Clin. Oral Impl. Res. 11 (2000) 314

3. M. CASTOLDI, M. PISTONE, C. CARUSO, A. PUDDU, C. FILANTI, D. PICCINI, C .TACCHETTI and P. MANDUCA, Cell Biol. Int. 21 (1997) 7

4. K. ANSELME, Biomaterials 21 (2000) 667

5. G. B. SCHNEIDER, S. W. WHITSON and L. F. COOPER, Bone 24 (1999) 321

6. K. M. YAMADA, Matrix Biol. 16 (1997)137

7. S. LEEUWENBURGH, J. WOLKE, J. SCHOONMAN and J. JANSEN, J. Biomed. Mater. Res. 66A (2003) 330

8. M. C. SIEBERS, X. F. WALBOOMERS, S. C. G. LEEUWENBURGH, J. G. C. WOLKE and J. A. JANSEN, J. Biomed. Mater. Res. A, accepted for publication

9. C. MANIATOPOULOS, J. SODEK and A. H. MELCHER, Cell Tissue Res. 254 (1988) 317

10. A. K. MCNALlY and J. M. ANDERSON, Am. J. Pathol. 160 (2002) 621

11. KJ. LIVAK and T. D. SCHMITTGEN, Methods 25 (2001) 402

12. S. GRONTHOS, K. STEWART, S. E. GRAVES, S. HAY and P. J. SIMMONS, J. Bone Miner. Res. 12 (1997) 1189

13. G. GRONOWICZ and M. B. MCCARTHY, J. Orthop. Res. 14 (1996) 878

14. J. VAN DEN DOLDER, G. N. BANCROFT, V. SIKAVITSAS, P. H. M. SPAUWEN, A. G. MIKOS and J. A. JANSEN, Tissue Eng. 9 (2003) 505

15. P. J. TER BRUGGE, S. DIEUDONNE and J. A. JANSEN, J. Biomed. Mater. Res. 61 (2002) 399

16. P. J. TER BRUGGE and J. A. JANSEN, Biomaterials 23 (2002) 3269

17. J. E. DE RUIJTER, P. J. TER BRUGGE, S. C. DIEUDONNE, S. J. VAN VLIET, R. TORENSMA and J. A. JANSEN, Tissue Eng. 7 (2001) 279

18. P. J. TER BRUGGE, R. TORENSMA, J. E. DE RUIJTER, C. G. FIGDOR and J. A. JANSEN, Tissue Eng. 8 (2002) 615

19. Y. L. CHANG, D. LEW, J. B. PARK and J. C. KELLER, J. Oral Maxillofac. Surg. 57 (1999) 1096; discussion 1108-1109

20. H. CAULIER, S. VERCAIGNE, I. NAERT, J. P. C. M. VAN DER WAERDEN, J. G. C. WOLKE, W. KALK and J. A. JANSEN, J. Biomed. Mater. Res. 34 (1997) 121

21. J. E. HULSHOFF and J. A. JANSEN, Clin. Oral Implant. Res. 8 (1997) 393

22. K. L. KILPADI, P. L. CHANG and S. L. BELLIS, J. Biomed. Mater. Res. 57 (2001) 258

23. T. MATSUURA, R. HOSOKAWA, K. OKAMOTO, T. KIMOTO and Y. AKAGAWA, Biomaterials 21 (2000) 1121

24. T. J. WEBSTER, C. ERGUN, R. H. DOREMUS, R. W. SIEGEL and R. BIZIOS, J. Biomed. Mater. Res. 51 (2000) 475

25. J. CLOVER, R. A. DODDS and M. GOWEN, J. Cell Sci. 103(Pt 1) (1992) 267

26. G. A. GRONOWICZ and M. B. MCCARTHY, Endocrinology 136 (1995) 598

27. S. NAKAYAMADA, Y. OKADA, K. SAITO, M. TAMURA and Y. TANAKA, J. Biol. Chem. 278 (2003) 45368 